\title{
Subglottic Cancer pT4 TNM Finding v8
}

National Cancer Institute

\section{Source}

National Cancer Institute. Subglottic Cancer pT4 TNM Finding v8. NCI Thesaurus. Code C133125.

Subg lottic cancer with moderately advanced or very advanced disease. (from AJCC 8th Ed.) 